This item was submitted to Loughborough's Research Repository by the author.

Items in Figshare are protected by copyright, with all rights reserved, unless otherwise indicated.

\title{
Public ICT innovations: a strategic ambiguity perspective
}

PLEASE CITE THE PUBLISHED VERSION

http://dx.doi.org/10.1057/jit.2013.18

\section{PUBLISHER}

(c) Palgrave Macmillan

\section{VERSION}

AM (Accepted Manuscript)

\section{PUBLISHER STATEMENT}

This work is made available according to the conditions of the Creative Commons Attribution-NonCommercialNoDerivatives 4.0 International (CC BY-NC-ND 4.0) licence. Full details of this licence are available at: https://creativecommons.org/licenses/by-nc-nd/4.0/

\section{LICENCE}

CC BY-NC-ND 4.0

\section{REPOSITORY RECORD}

Ravishankar, M.N.. 2019. "Public ICT Innovations: A Strategic Ambiguity Perspective”. figshare. https://hdl.handle.net/2134/17124. 
Public ICT innovations: A strategic ambiguity perspective

\author{
M.N. Ravishankar \\ Loughborough University, UK
}

The full address for correspondence is as follows:

Dr M.N. Ravishankar

School of Business and Economics

Loughborough University, Loughborough

Leicestershire LE11 3TU, UK

Phone: +441509228823

Fax: +441509223960

Email: M.N.Ravishankar@lboro.ac.uk

Web: http://www.lboro.ac.uk/departments/sbe/staff/academic-research/bsrm6.html 


\title{
Public ICT innovations: A strategic ambiguity perspective
}

\begin{abstract}
Public ICT innovations are seen as having the potential to usher in a new era of technologyenabled models of governance in emerging economies. While it may be desirable for the implementation of such innovations to be underpinned by precise planning, structure and clarity, policy implementers in emerging economies are confronted instead by situations where ambiguous goals and means are standard. This paper considers high levels of ambiguity as a relatively enduring and intrinsic aspect of public ICT innovations in emerging economies. Drawing on an ethnographic study of Bangalore one (B1), an innovative public ICT project implemented in Bangalore, India, the paper examines how strategic ambiguity is deployed by key public actors to chart the course of the implementation process and to steer it towards reasonable outcomes. Theoretically, the paper suggests that although strategic ambiguity is a precarious and unsettling condition in general, it can work effectively in contexts that are reasonably tolerant of ambiguous norms. The findings of the study also present arguments for why evaluation mechanisms need to be fundamentally reframed in order to assess the extent of implementation success of public ICT innovations in emerging economies.
\end{abstract}

Key words: Public ICT innovations, Ethnography, India, Strategic Ambiguity 


\section{Introduction}

The Information and Communications Technology (ICT) revolution of the past two decades has ignited many public sector-driven innovations in emerging economies (see Walsham and Sahay, 1999; Puri and Sahay, 2007; Sahay et al., 2010; Stafford and Turan, 2011). Some 'success stories' have managed to achieve an almost legendary and mythical status in the global imagination. For instance, during a visit to Silicon Valley in California on the eve of the 2004 US elections, the presidential candidate John Kerry is reported to have remarked: "We need a leadership that says if Bangalore in India can be completely wired, then so should all of America." Of course, this comment was a spectacular misrepresentation of the commitment levels of the political leadership in Bangalore to ICT and of the penetration achieved by high speed broadband services in that city. But it is evident that Kerry’s flawed observations were triggered by the growing numbers of government-led ICT innovations that are being embarked upon by emerging economies to improve governance and to provide a wider range of essential services to citizens. In this paper, I refer to such innovations as public ICT innovations. Very broadly, they may be defined as creative and imaginative government-led applications of ICT that aim to provide public goods and services in new or significantly improved ways (see OECD, 2011).

Empirical work on public ICT innovations in emerging economies have provided mixed evaluations. Some studies have demonstrated how such innovations fail to achieve intended objectives owing to highly centralized decision-making bodies, lack of political will, apathy of senior officials, corruption and asymmetries of power (see Heeks, 2002; Kimaro and Sahay, 2007; Heeks and Stanforth, 2007; Sahay et al., 2009; Bussell, 2012). Others have painted a more positive picture arguing that public ICT innovations in emerging economies have slowly but surely reduced information asymmetries and bridged digital divides (see Kanungo, 2003; James, 2004). 
Public ICT innovations play a crucial role in emerging economies, which are stricken by what Khanna and Palepu (1997, 2010) have called 'institutional voids'. Institutional voids refer to the conspicuous absence of institutional mechanisms that allow sellers and buyers to come together efficiently. If we consider governments as a key provider (or seller) of public services and citizens as consumers (or buyers) of these services, then it is evident that public ICT innovations serve as important institutional mechanisms that fill institutional voids and bring public services to citizens more efficiently and innovatively. Public ICT innovations also provide good business opportunities for private players (Kuriyan and Ray, 2009). Many models follow the public-private partnership approach wherein private sector partners participate as intermediaries in the design and implementation of public ICT innovations (James, 2004; Madon, 2005).

Despite the optimism surrounding them the implementation of public ICT innovations in emerging economies is by no means a straightforward process. Such innovations confront all the well-known barriers associated with public sector initiatives (see Ring and Perry, 1985; Yackee, 2012), which are further amplified in a context of multiple institutional voids. As a result, the planning and implementation of public ICT innovations is invariably accompanied not by high degrees of structure, order and clarity as desired, but rather by high degrees of ambiguity. Much of the literature on emerging economies applies command and control models of management to these difficulties and suggests a series of formal mechanisms as possible solutions. These include industry-inspired performance management systems (Saxena, 2005), the strategic alignment of national and local government ICT policies (Weerakkody et al., 2012) and the use of carefully designed and calibrated ICT governance maturity models (Valdes et al., 2011). Such recommendations are known to fail at three levels (see Matland, 1995). First, they often provide simplistic 'what to do' lists ignoring the history and the embedded institutional voids that render such lists fanciful. Second, they tend 
to view implementation as a largely administrative process, where political aspects can either be ignored or eliminated. Third, they end up emphasizing inadequacy of resources as an important factor affecting innovations, which in most cases is an accurate but unhelpful diagnosis. Thus, the overwhelming focus tends to be on 'what should be' while ignoring the social realities of situated actors who can only work with 'what is'.

At the heart of the dominant approaches to public ICT innovations in emerging economies is the implicit notion that there is way too much ambiguity in their implementation and that serious formal efforts must be invested in eliminating ambiguity. But this can be a very simplistic and even utopian viewpoint. As a point of departure from such a stance, this paper considers ambiguity as an inherent and relatively enduring feature of the evolution of public ICT innovations in emerging economies and not as something that can be dismantled by forceful action (see Matland, 1995; Sahay et al., 2009). This viewpoint demands close attention to how actors engage with ambiguity. Strategic action, then, can be understood as being actively shaped both by the ambiguity of the context and by the ways in which actors' approaches reflect these ambiguities (Jarzabkowski et al., 2010; Sillince et al., 2012). Actors can adopt seemingly ambiguous positions in a strategic way and help steer innovative ICT projects. Building on these ideas, this paper explores the role of strategic ambiguity in the implementation of public ICT innovations in emerging economies. The main arguments of the paper are supported by a five-year ethnographic study of the implementation of Bangalore one (B1), a public ICT innovation project in Bangalore, India, which provides a range of integrated citizen-centric services.

\section{Strategic ambiguity}

For many years now, scholars have debated the significance of ambiguity in the evolution and implementation of strategy (see Eisenberg, 1984; Matland, 1995; Davenport and Leitch, 
2005; Jarzabkowski et al., 2010; Sillince et al., 2012). The notion of strategic ambiguity runs counter to the idea that those in leadership and managerial positions rely largely on clarity, precision and openness to drive effective action. Proposed by Eric Eisenberg (1984) as an alternative to theories that emphasize the efficacy of open communication and clarity, strategic ambiguity broadly refers to the purposeful and deliberate use of vagueness or/and incompleteness in devising and articulating strategy. At the heart of the notion are a series of astute arguments by sociologists about how in many social and organizational endeavours actors often have enough strategic reasons to obfuscate and conceal (see Burke, 1962; Goffman, 1963). Epistemologically, the idea of strategic ambiguity draws heavily on the symbolic interactionist view of the world, which has shown us how shared meanings are very hard to achieve in any interactive setting, given the complex interpretative forces at play (Blumer, 1969; Goffman, 1974).

Organizational actors are known to create and work with three broad dimensions of ambiguity: Goal ambiguity, which refers to the presence of vague and unclear objectives; authority ambiguity, which refers to the ambiguity created by the presence of multiple authority and power centers; and means ambiguity, which refers to unclear relationships between goals and the means to achieve them (Cohen and March, 1986; Jarzabkowski et al., 2010). While the concept can be traced back to scholarship mainly in communication studies, sociology and linguistics, as a theoretical frame strategic ambiguity has now gained much traction in many diverse fields. Scholars writing about international relations, for instance, have examined how strategically ambiguous security commitments are at the heart of US policies towards the Taiwan Straits conflict (Benson and Niou, 2001). More recently, Jarzabkowski et al. (2010) and Sillince et al. (2012) showed how different groups within a UK business school used strategic ambiguity as a discursive resource to assert their own interests in relation to the school's 'internationalization' goal, while simultaneously 
accommodating wider interests. Empirically, this study argued that ambiguity can be a useful device to artfully manoeuvre around potentially conflicting situations and to guide strategic action. On the other hand, a recent study by the management consulting group Deloitte links strategic ambiguity to disastrous results and urges organizations to embrace 'strategic clarity' instead (Deloitte, 2012).

\section{Ambiguity: the two schools of thought}

In general, there are two prominent and contrasting schools of thought about ambiguity, which have a special significance for innovative projects in the public sector. The first school of thought presents ambiguity as a highly problematic condition, which inhibits strategic action (see Jarzabkowski et al., 2010). The proponents of this perspective have been broadly referred to as the 'top-downers' (Matland, 1995), who emphasize clarity, clear unambiguous rules, consistency and elimination of all conflict. Implementation of public sector ICT innovations in this perspective occurs through centrally-planned top-down models, which can then produce generalizable policy recommendations. Ambiguity is seen as an unwanted and even unethical condition that can potentially lead to dangerous and uncontrollable consequences (see Paul and Strbiak, 1997). Predictably, the top-down school of thought argues for a push towards greater clarity and minimization of ambiguity along all of its dimensions (goals, authority and means) noted earlier.

The over prescriptive tone of the first school has been criticized in a second perspective on ambiguity, whose supporters have been termed as the 'bottom-uppers' (Hjern and Hull, 1982; Matland, 1995). This group of scholars have called for a more realistic understanding of the ambiguous contexts within which projects are initiated in the public sector. This paper draws mostly on this second perspective. Although centrally located actors may announce an innovative project, actors involved in the micro implementation process (e.g., bureaucrats, 
local government officials and private sector intermediaries) confront numerous challenges in adapting the broad plan to the local environment. In highly charged local political environments the aspirations of many stakeholder groups need to be given consideration (Madon et al., 2004; Mistry, 2005). But the resources necessary for implementation can be controlled by different organizations (Davenport and Leitch, 2005). Conflicts and power struggles between various government agencies can sabotage innovative projects even before they are implemented. The issues surrounding the ambitious unique identification number (UID) project in India is a case in point (see Mukherjee and Nayar, 2011). Multiple audiences may attribute different meanings to the design and implementation of projects, leading to conflict (Jarzabkowski et al., 2010). Often, the implementation process is closely monitored by well-meaning civil society groups, who, however, fail to sympathize with the political aspects of the implementation (see Bussell, 2012) and are quick to pounce on any deviations from the original proposals. Implementation teams also face a great deal of pressure to present information about innovations in a manner that creates a positive image and reputation for the government.

These challenges in the micro-environment inevitably introduce uncertainty and vagueness about the goals, strategies, activities and processes underpinning implementation. Thus, ambiguity can be seen as an inherent aspect of the design and implementation of innovations in the public sector. From this perspective, since it is an intrinsic and relatively enduring condition of the system, realistically ambiguity can neither be easily manipulated or eliminated in line with the first school of thought's recommendations. Therefore, this bottomup perspective describes a flexible and decentralized approach that may emerge in synchronization with the local needs and difficulties (see Walsham, 1992). Overall, this school of thought emphasizes the point that embedded ambiguities are permanent fixtures in the micro-institutional settings of public sector innovations (see Lowi, 1979; Matland, 1995; 
Nooredgraf and Abma, 2003). In such settings, actors’ deployment of strategic ambiguity can play a crucial role in steering projects towards reasonable outcomes.

\section{The role of strategic ambiguity}

According to Eisenberg's (1984) theory, strategic ambiguity has the capacity to perform four important organizational functions, which also echo strongly in the empirical sections of this paper. First, it can 'foster agreement on abstractions without limiting specific interpretations' (Eisenberg, 1984: 9). For example, abstract, but positive sounding mission statements and objectives invoked during the implementation of an innovative public sector project can result in different groups agreeing to work together, although in reality each group may have a different interpretation of the abstractly worded initial positions. Eisenberg (1984) referred to such a condition as the accomplishment of 'unified diversity'. Second, ambiguously stated initial goals give organizational actors the flexibility to revise current interpretations of such goals (see Edwan, 2009). According to Eisenberg, this flexibility to shift interpretations of goals in response to environmental constraints helps overcome conflicts and facilitates systemic changes in an incremental manner. Third, strategic ambiguity can also be a means of keeping self-serving external partners on their toes, by providing only a general overview of a given situation (Leitch, 2002) and by not divulging the full set of possible details relating to a project. In this sense, strategic ambiguity can help 'preserve the privileged positions' of key actors (Eisenberg, 1984). Finally, strategically ambiguous communications are deniable. In other words, because they are always open to multiple interpretations, any narrowly defined and potentially embarrassing projection can be easily dismissed by authorities on the grounds that such a specific interpretation was never intended in the first place (Matland, 1995).

\section{Public ICT innovations, emerging economies and strategic ambiguity}


Overall, these arguments about complex implementation contexts and the possible accomplishments of strategic ambiguity can be applied usefully to the study of public ICT innovations in general and to their study in the context of emerging economies in particular. With rapid advances in technology, public ICT innovations are increasingly viewed as central to improved governance and overall development of nations. For governments, ICT innovations help introduce key public sector reforms in a transparent manner. Specifically, they hold the promise of bridging digital divides and reducing information asymmetries (Kanungo, 2003; James, 2004; Mistry, 2005), improving flow of information between government departments (Heeks, 2000), streamlining national health care systems (Kimaro and Sahay, 2007; Madon et al., 2007), contributing to the development of rural areas (Prakash and De, 2007; Kuriyan and Ray, 2009) and minimizing corruption (Puri and Sahay, 2007; Smith, 2011; Bussell, 2012). Clearly, from the perspective of the citizens, such innovations can provide easier and more dependable access to a spectrum of public services. They may also help citizens avoid bureaucratic hurdles and push middle-men out of the equation (Heeks, 2010). In short, public ICT innovations have the potential to transform delivery of public services and to thus generate significant public value in a society (see Cordella and Bonina, 2012). In the context of emerging economies of course, public ICT innovations are now essential policy instruments and yet at the same time their benefits are particularly challenging to realize given the uncertainties in the institutional environment (Heeks and Stanforth, 2007; Sahay et al., 2010; Bussell, 2012).

The work of Sundeep Sahay, Shirin Madon, Richard Heeks and other colleagues offer vivid accounts of ambiguities in emerging economies' public ICT innovations in relation to the sustainability and scalability of projects (Heeks, 2000; Madon et al., 2007), appropriateness of technology (Sahay et al., 2010) and tendering processes and contracts (Sahay et al., 2009). Such ambiguities intrinsic to the implementation settings can be further exacerbated by the 
prevailing institutional voids. In other words, the ambiguities are worsened when institutional mechanisms (e.g., print and electronic media outlets) that ought to function as 'credibility enhancers' and 'information analyzers and advisors' are not mature enough (or not present at all) and therefore create more confusion instead of providing revelatory insights (see Dhanraj and Khanna, 2011: 689). Indeed, there is now a growing body of empirical studies that illustrate the links between embedded ambiguities in emerging economies and the absence of institutional structures that can effectively perform the role of regulators, auditors, information analyzers and legal adjudicators (see Khanna and Palepu, 2010; Dhanaraj and Khanna, 2011).

If we take the analytical position that public ICT innovations in emerging economies are invariably implemented in contexts of relatively enduring ambiguity rather than clarity, the question then is: how do actors responsible for implementation deal with and respond to ambiguity? The scholarly literature suggests that when resolving them is mostly not an immediate option, actors work to actively exploit ambiguity as a possible resource for action (Vaara, 2002; Davenport and Leitch, 2005). In ambiguous contexts, actors purposefully construct and utilize ambiguity to guide the implementation process (Eisenberg and Goodall, 1997; Jarzabkowski et al., 2010). Ambiguity can indeed have many positive effects, particularly when institutional voids add many layers of uncertainty and complexity, and threaten to paralyze the implementation of public ICT innovations. As I will argue in the subsequent discussion sections of the paper, deliberate deployment of ambiguity can generate useful abstractions (Ring and Perry, 1985), establish a working consensus between stakeholders (Regan, 1984; Sillence et al., 2011), enable shifting interpretations of project goals (Davenport and Leitch, 2005) and restrict information flows (Leitch, 2002). In the next sections of the paper, I expand on the role of strategic ambiguity in the emerging economy 
public ICT innovation context through an analysis of the implementation of the Bangalore One (B1) project in Bangalore, India.

\section{Research methods}

I adopted the interpretive ethnography approach (Myers, 1999) over a five year period to study the implementation of the B1 project. Interpretive methods of enquiry argue that 'our knowledge of reality is a social construction of human actors' (Walsham, 1995: 376). Rather than take a deterministic point of view, interpretive methods aim to understand phenomena through the meanings informants assign to them. In other words, interpretive approaches largely explore phenomena within a particular cultural and contextual setting from the perspective of the informants.

Ethnographic research involves lengthy and extended fieldwork among informants and therefore allows the researcher to get a ring-side view of the action (Van Maanen, 2011; Ravishankar et al., 2012). Such a deep immersion in the field helps ethnographers to enter the social and cultural worlds of the informants and to throw light on various emerging issues of interest. Much of the early ethnographic research was undertaken by sociologists and anthropologists who strongly believed that a fuller understanding of a community's culture and ways of life was only possible through an intensive - much more intensive than what could be achieved through case study and survey methods - period of face-to-face contact with situated individuals and groups (see Goffman, 1961; Van Maanen, 1979; Hammersley and Atkinson, 2007). Thus, ethnographic research is characterized by intensive fieldwork where the researcher gathers empirical material from the 'native's' point of view (Malinowski, 1922) using a range of techniques including participant observation and informal interviews. Partly because the method has been picked up over the years by scholars in diverse fields and partly because it is a loaded term with obvious orientalist connotations, 
the word 'native' has now more or less disappeared from ethnographic descriptions of organizations and projects. But the ethnographic approach itself has continued to grow in popularity. A number of recent ICT-related studies have a clear ethnographic orientation (see Rangaswamy and Sumitra, 2010; Ravishankar et al., 2012). Further, even many technology firms now extensively use ethnographic techniques to study the everyday actions and accounts of people in their natural settings (see Kerschberg, 2012). In my case, the ethnographic style fieldwork was particularly useful because it helped me explore, explain and uncover in great detail the processes through which the key players in the B1 project handled everyday situations and guided the course of the project.

In contrast to classic ethnographies in the anthropological tradition where the researcher is an outsider in all respects, I was fairly familiar with the broader cultural milieu having lived in Bangalore for 25 years. The challenges of linguistic competence, access to informants and cultural skills were therefore significantly reduced. However, the research setting itself was a somewhat unknown territory since I had very little experience of conducting intensive fieldwork within public sector settings in India (see Karra and Phillips, 2008 \& Cohen and Ravishankar, 2012, for a detailed discussion on 'insiders' and 'outsiders' in fieldwork based research).

\section{Research Setting}

Bangalore One (B1) is a public ICT project launched by the Electronic Delivery of Citizen Services (EDCS) Directorate, Government of Karnataka ${ }^{\mathrm{i}}$, India, in 2005. B1 is viewed as a good illustration of a public ICT innovation for several reasons. First, the project harnesses existing ICT applications to create (for the citizenry) newer channels of interaction with diverse government departments. By many accounts it is now seen as a project that draws on ICT to deliver a range of public services in more efficient and effective ways than previously possible in this setting. Second, the operationalization of the ICT-driven project is novel in 
that it is extremely sensitive to the challenges of the digital divide that grips many emerging economies. The administration of the project is based on an inclusive rather than an exclusive definition of the general public serviced by it. Third, the working business model of the project appears viable, sustainable, easily scalable and applicable to many other emerging economy settings. Lastly, the project generates public value through a collaboration model that innovatively draws on the competences of private sector partners. Thus, it can be viewed as a project that uses ICT applications to facilitate the co-creation of innovation (Rai et al., 2011) in the public sector.

B1 provides a range of citizen-to-government (C2G) and citizen-to-business (C2B) services in Bangalore (see Table 1 and 2). Within the EDCS Directorate, the 'B1 team' is responsible for the implementation of the project. The B1 team comprises a handful of senior, middlelevel and junior government bureaucrats, who are supported in their work by a small group of software engineers and information technology (IT) consultants. B1 follows a public-privatepartnership model in which the everyday operations are run by a private vendor consortium comprising of two IT companies and a commercial bank. I refer to this private consortium as PCON in this paper. Citizens can access services provided by various government departments (C2G) and private businesses (C2B) in two ways - by visiting the B1 citizen service centers (CSCs) located in different parts of Bangalore city and via the B1 website (see Table 1 and 2). B1 is a purely commercial venture for PCON, which is paid a nominal service charge for each transaction. PCON manages the ICT software and hardware infrastructure for the project and also operates 75 CSCs in Bangalore.

\section{Integrated Services through the B1 website}

PCON has designed the B1 website using Microsoft's .NET platform-based e-Governance framework. Any citizen can register on the B1 website and is given a user name and password to access the available online services (see Table 2 and Appendix A). The data 
center of B1 is integrated with the IT systems of the participating departments whose services are offered through the project (see figure 1). Whenever a customer logs in to the B1 website and requests for a service from a particular department, the integrated B1 records management system retrieves the customer details from the concerned department's IT system, allows the customer to complete the transaction and prints a receipt. The updated record of the customer subsequently gets reflected in the particular department's IT system.

\section{Integrated Services through the CSCs}

Citizens also access the services provided by the B1 project at walk-in CSCs. As noted earlier, there are now 75 CSCs in the city, some of which operate round the clock on all days of the week. The government provides furnished space for the CSCs, while PCON is responsible for setting up the ICT infrastructure and running the everyday operations. Each CSC is headed by a manager, who is assisted by about 20 customer-service representatives (CRs). The CRs sit at transaction counters, which are equipped with computer terminals connected to the central B1 data center (see Figure 1). All CSCs are equipped with an electronic queuing system. Customers walk in to a CSC, collect a queue number and get directed to transaction counters, where CRs assist them (see Appendix B). When a customer requests for a particular service, the CR links up to the central B1 data center through his/her respective terminal, retrieves the customer records, collects payment from the customer (where relevant) and updates the records. The customer is given a receipt and as with the transactions conducted through the B1 website, the updated records are sent electronically to the concerned department and are soon reflected in that department’s IT systems.

\section{Data Collection}

I contacted the director of the B1 team in early 2006 and expressed my intention to study the B1 project. He was kind enough to offer support for my proposed fieldwork and he put me in 
touch with his team members, PCON managers and managers of the different CSCs. I then conducted six rounds of fieldwork in Bangalore over a five year period (see Figure 2). Each round of fieldwork lasted for about 20 days. During each round of fieldwork I collected data through a variety of means. I conducted a number of formal and informal interviews with members of the B1 team, PCON managers, CSC managers, CRs and citizens ${ }^{\mathrm{ii}}$. In total, I interviewed 96 informants. It is hard to report on the actual number of interviews since many of the informants were interviewed multiple times during fieldwork. Since I am bi-lingual I was able to conduct and manage interviews with reasonable confidence both in English and Kannada ${ }^{\mathrm{iii}}$. Most of the interviews were not digitally recorded, but detailed notes were made during and after the interviews. This practice is quite common during fieldwork in such research settings (e.g., Madon et al., 2004).

All the interviews were conducted at the work place of informants. The interviews with citizen informants were conducted at the respective CSCs where they accessed B1's services. I did not use a structured interview guide in the initial rounds of fieldwork since I was more focused at that stage on building a good rapport with informants. In the early phases, I allowed informants to speak freely about the B1 project, interjecting only occasionally with a query or two. But I used the material from these early interactions as a guide to formulate semi-structured open-ended questions during subsequent rounds of fieldwork. The questions covered the evolution of the implementation process and included queries on how the B1 team managed their relationship with the different stakeholders of the project. I also spent many hours at the CSCs observing informants in action. Valuable inputs were gleaned through a number of informal conversations with informants before and after the interviews. These conversations provided rich accounts of the key issues and conflicts confronting the project. I also accessed additional data about the B1 project through government reports, the 
B1 website, newspaper articles, discussion forums on the internet and commentaries in the business press.

\section{Data analysis}

A starting point for the analysis was the impressions formed during the first couple of rounds of fieldwork, which were held within two years of the launch of the B1 website and the CSCs. In the interviews and observations, informants in the B1 team and the PCON team frequently referred to the lack of clarity in the system, which they felt underpinned all public ICT implementations in India. Concurrently, I read the detailed notes corresponding to the interviews and observations. During this process, I identified several extracts that suggested vague statements of intent and objectives for the project. I then went back to the scholarly literature in search of a suitable framework that could explain the initial findings and also serve as a sensitizing analytical frame for the subsequent rounds of fieldwork. Through an iterative and recursive process of relating the preliminary fieldwork data to broader theoretical frameworks, I arrived at the idea of conceptualizing strategic ambiguity as a potential guiding framework for the study. Thus, although I have presented the paper using the conventional linear structure in order to assist readability and comprehension, the process of developing the paper was inevitably circular, as is the case with most ethnographic work.

In the next few rounds of fieldwork, I focused mainly on how the main groups of actors shaped and guided the implementation, and on their description of the process. At the end of the fieldwork, I adopted a 'selective' scheme (Strauss and Corbin, 1998) to identify dominant themes from the field notes and interviews, which highlighted the B1 team's use of ambiguous and vague strategies at various phases of implementation. For instance, 'marketing uncertainty' and 'e-governance semantics' were two main themes identified during this coding process. Essentially, these dominant themes were inductively abstracted descriptions of the B1 team's intentional use of equivocation in their interactions with PCON 
and with the wider citizenry. I then analyzed the linkages between the ambiguous approaches of the B1 team and the outcomes of the project. I tried to minimize the possible biases linked to my interpretations by triangulating the data through multiple informants from all the relevant stakeholder groups. I then constructed a narrative of how the B1 team shaped and guided the implementation process. This narrative was modified and amended slightly in response to comments from informants about some factual inconsistencies in my description of the case.

\section{Case description}

The B1 project is regarded as an important innovation and a success (see Government of Karnataka, 2010; Sarkar, 2011). Before the implementation of the project, accessing the services that are now easily obtained via the B1 website/CSCs was a very chaotic and harrowing experience for citizens. They had to travel to different office locations in the city to transact with different departments. Sometimes, the bureaucratic maze was so bad that closely related services of the same department instead of being offered under a single roof required citizens to go to multiple locations in different corners of the city. It was not uncommon for citizens to literally run from one far flung location to another to get their work done. Customer-facing units of many departments remained open only for few hours a day and were notorious for their poor levels of service and less than transparent practices. CSCs, on the other hand are open 24 hours day and staffed with CRs who are more often than not, polite and courteous. Also, hearteningly for the B1 project there have been no reports or accusations so far of corruption/wrong-doing against any of the CRs. The average walking distance to any CSC is $2 \mathrm{~km}$, which is a big advantage in a city known for inadequate public transport facilities. According to official estimates, more than one million citizens access C2G and C2B services at the CSCs every month (EGovReach, 2012). 
In this paper, I examine the B1 project from the perspective of the B1 team, which in the process of planning, designing and implementing the ICT-based project has had to manage numerous expectations and complex relationships with different stakeholder groups. As a public policy innovation, the B1 project began with a great deal of ambiguity. The aspirations of the political establishment, which proposed the project, were lofty, but extremely short on detail. For instance, the original mandate for the B1 team was to demonstrate through the project that the Karnataka state was 'No 1 in ICT-enabled governance'. Obviously, this mandate was open to multiple interpretations. The unclear meanings, however, helped get the required legislative approval for the project. Political parties dared not oppose a project with such a noble and progressive objective. Also, reports of a neighbouring state having recently implemented an innovative public ICT governance project had created a heightened sense of competition in Bangalore. The political leadership was keen to implement a project, which would improve its image significantly as a technology-led government.

Although in theory the neighbouring state’s project was a starting point for B1, a high degree of ambiguity was in-built into the implementation process. The B1 team only had a very general notion of what a full-fledged public ICT governance model ought to look like. Many contextual variations in the availability of resources, expectations of the general public, technology preparedness of the relevant parties and in the anticipated levels of support from different government departments added to the uncertainty. There were question marks over the means through which excellent outcomes could be achieved. Whether the B1 team could exercise enough authority over various government departments whose cooperation was vital for the implementation of any innovation was a moot point. The technological means through which the state could become 'No 1' was also unclear. Thus, high levels of ambiguity existed about the objectives of the project, the means to achieve the objectives and whether the B1 team could exercise control over multiple entities. As noted in the review of the literature 
above, these dimensions of ambiguity have been respectively referred to as goal ambiguity, means ambiguity and authority ambiguity (see Cohen and March, 1986; Matland, 1995). In the sections below, I trace the evolution of the implementation process with particular reference to how ambiguity was deliberately employed by the B1 team in its activities and interactions.

\section{Ambiguity in establishing the project's scope}

At the start of the project, the B1 team released a 'scope of work' document aimed at prospective vendors, which covered many areas of the proposed project:

"We felt that the scope of work had to be all-encompassing. It had to be broad and general so that multiple interpretations were possible. We had to be non-committal on many fronts because this was going to be a complex project. We were committed to the project, but we could not be too specific since things were not too clear." (B1 team informant)

The idea was to describe the implementation model, the technical specifications and the manpower requirements in broad terms so that the selected vendors would not be able to back out of their commitments easily in case the B1 team suggested a particularly demanding IT integration project in the future. From the B1 team's point of view there were many useful directions in which the project could potentially proceed. But all of them depended heavily on the intensity of participation and commitment of a range of actors outside their direct control:

"From a governance and administration viewpoint, we would like the B1 project to be a very effective intervention. We have big plans to streamline and regulate income tax and property tax revenue processes, to monitor and regulate land registration and transfer practices and so on. We want to ensure that government departments are more transparent and accountable to citizens. But we know that achieving all of this will require systemic changes 
outside our control. So we will do whatever we can to help citizens. Committed bureaucrats can plug many holes in many ways through such projects. Yes, I freely admit that with so many variables it is hard to say whether things will work out the way we want them to. In fact, it is hard to say anything with clarity and certainty about the project." (B1 team informant)

This type of implementation has been described as the 'garbage can' process of decision making, where multiple actors, multiple problems, numerous solutions and choice opportunities combine to produce outcomes that are hard to predict (Cohen et al., 1972; March and Olsen, 1976; Matland, 1995). In this process, ambiguity cannot be resolved but decisions emerge depending on how actors respond to ambiguity from within the garbage can (Sillince et al., 2012). The B1 team responded to the inherent ambiguity of the context by coming up with very broad descriptions of the project, which however, succeeded in generating interest from vendors:

"The main theme was improved governance through a range of ICT-enabled citizen centric services. This could mean anything. You can have relatively simple services like utility bill payments to fairly complex processes like income tax calculation and payment services. So although we were worried, we bid because we had some experience of working in this domain. The worry was of course what if we are asked to do something really complex outside our current capabilities. No enterprise would like that. But because the language initially was vague, it helped us take the first step.” (PCON informant)

By the time PCON was selected as the vendor consortium, the B1 team had identified a number of simple public utility bill collections (e.g., electricity, water and telephone) that could be facilitated with reasonable success through the project:

"We worked bottom-up. We asked ourselves the question - what are the areas in which citizens struggle in their interactions with government departments due to inadequate 
facilities and poor service? We consulted with local elected representatives and citizen groups. We then tried to see if we can fill in these gaps. You must appreciate that at that stage in Bangalore, paying your utility bills was not at all a smooth experience.” (B1 team informant)

\section{Ambiguity in the relationship with PCON}

The B1 team knew that in an absolute sense these bill collections addressed only the very basic problems of governance. There were several difficulties in taking the project forward through more ambitious innovations. The ICT infrastructure in many government departments were in a bad state. Many departments were also extremely reluctant to be a part of any initiative that might potentially lead to greater transparency and accountability requirements. Although as noted earlier, they planned to add new and advanced C2G services (for e.g., ICT-enabled streamlining of access to land title registers) in a phased manner, the B1 team faced numerous barriers. They were well aware that many public ICT innovations started in various parts of India with much fanfare and ambition had ended up failing, offering nothing much of value to citizens. Senior officials in the B1 team viewed the project as a process of experimentation. They wanted to be incrementally ambitious in the type and range of services they offered to citizens via the B1 project. But what they certainly did not want was to be tied down to a set of services that were commercially attractive for the vendor, with only a tangential connection to the larger public interest. This was one of the main reasons for presenting a deliberate lack of clarity in their interactions with PCON:

"For PCON, this is first and foremost a commercial enterprise. For us, we have to look at what exactly the citizens are going to get out of it. Naturally, they (PCON) just want to set up the network and make money out of each transaction. They do not really want to get involved in any way with the mess of dealing with other government departments. But this is precisely 
what is needed to deliver governance through ICT. Their stand is perfectly understandable. They'd perhaps prefer dealing only with private enterprises, which will turn the project into a $C 2 B$ rather than a $C 2 G$ project. But we want the project to be mainly about C2G. Therefore the specifications are quite broad and not restrictive from our perspective. Our main focus is C2G. So we can't turn this into a C2B affair. We have to keep things somewhat unclear so that PCON don't get the wrong ideas. But we still need PCON!” (B1 team informant)

"Some of the language was all over the place. We were scratching our head wondering what it all meant. At one point they brought out something called a rough condensed detailed project report!” (PCON informant)

Despite the B1 team's intentions to position the project as citizen-centric and not PCON centric, the project has come in for some sharp criticism for including C2B services in its portfolio, which critics argue favours only PCON and the private companies providing the business services (see Table 1 and Table 2 for a list of C2B services offered through the project). The B1 team has been consistently very ambiguous about the C2B components of the project, which it steadfastly underplays, choosing instead to highlight the C2G services offered by B1:

"It is always possible to add some C2B service because the CSCs are quite convenient to access for citizens. In a way, C2B services are also important for a growing city like Bangalore where there are many opportunities to make things easier and better for citizens. PCON is always pushing for adding new C2B services. But we have to protect the sanctity of B1, which is a government project. So it is much better to include some C2B services, but not talk about them too much as we go along. It is easier to be vague about their relevance to the goals of the project." (B1 team informant)

\section{Marketing the B1 project}


Over time, the project has become more structured and financially viable as more services have been added (see Government of Karnataka, 2010). The government has convinced many of its departments to align their technological infrastructure with the requirements of the B1 project. For example, as a B1 team informant explained, BESCOM (the electricity department), which had hitherto adopted an outdated distributed billing model was persuaded to invest in a leased line network that enabled data transmission from its central department server to local offices where customer records are maintained. The leased line infrastructure ensured that customer payments made at any CSC got updated in the records of the local offices in real time. With more services being added to the B1 project, the question of aggressively marketing the project came up. The B1 team was purposively unclear in committing itself to marketing the B1 project. It only promised to 'support' the marketing of the initiative without specifying the exact nature of this support. One reason, of course was that the B1 team worked within financial constraints and did not want to engage an external marketing agency. But there was another reason:

"We were hoping that the CSCs would be creative and innovative in marketing B1 locally. We did not want it to be a top-down rule based thing. We wanted to give them space. This is the reason why we were quite ambiguous about it.” (B1 team informant)

PCON was initially very surprised at the lack of direction from the B1 team about the overall marketing strategy for the project. But they realized that this ambiguity gave them the discretionary space and freedom to market the initiative without having to worry about complying with top-down bureaucratic rules and procedures. For instance, they did not have to create a separate marketing team or submit a detailed marketing plan to the B1 team and wait for their comments and approval. In fact, till date, despite its popularity the B1 project has not been guided by a formal marketing strategy: 
"We were a bit puzzled that we had so much freedom. We do not have marketing degrees or anything. But I took a couple of CRs along with me and did a door-to-door marketing campaign for two months, going to people's houses, explaining to them the services offered at the CSC and inviting them to make use of the services.” (CSC manager)

The B1 team's ambiguity towards marketing can also be viewed as a particularly clever strategic ploy given that it is completely in PCON's interest to market the initiative aggressively. After all, PCON makes money out of every transaction facilitated by the B1 project. The B1 team's ambiguous approach towards marketing resulted in each of the CSCs getting complete freedom to promote B1 locally. This approach echoes Davenport and Leitch's (2005) observation that strategic ambiguity can delegate authority to stakeholders in a way that is enabling rather than controlling. Clearly, the thinking behind the B1 team's vague attitude towards marketing was the assumption that PCON would respond with creative localized strategies to attract customers. Thus, ambiguity empowered the individual CSCs to improvise and devise suitable marketing strategies locally to attract customers.

\section{Ambiguity in public communications}

In the first few years of implementation, the B1 team framed the project as an e-governance innovation. The intended audience for this language of e-governance was the general public. There is a view that Bangalore's well-known global image as a ICT hub has not really trickled down to government organizations and that they have failed to take advantage of the global improvements in ICT. The B1 team felt that the term 'e-governance' aptly reflected its ambitious plans for the project. Also, the B1 team knew that the image of the government could get a boost by positioning the project as a novel e-governance project. While this message of e-governance was sufficiently ambiguous given the context, many technologycentric citizens in the city expressed scorn at these claims and challenged the definition of the 
B1 project as an e-governance project. These voices of disapproval became louder as it began to appear that only very basic services were offered by the B1 project. Many criticisms appeared, particularly in the electronic media and in discussion groups of online citizen forums. It was pointed out that e-governance innovations in developed countries offered services that are quite advanced when compared to the services offered through B1. Some criticized the project for simply being an outlet for collecting utility bills and for offering many C2B services in the guise of e-governance:

"When B1 began, it was very clear from what they told us that this was going to be an egovernance project. But there is as yet no sign of true e-governance. So why are they calling it an e-governance project? This is unbelievably misleading.” (citizen informant)

The B1 team was, however, unperturbed:

"Positive changes have to take place in an incremental fashion. Without understanding the context if we fight global battles on our turf, ultimately the citizens will suffer. So it is important that we make a start, which we have done. If someone is unhappy with the lack of sophisticated services or whatever, it is their choice. We are more focused on bringing out a transformation in the way citizens access services and in this, I think we have succeeded to an extent." (B1 team informant)

But in response to the criticisms, the B1 team removed the term 'e-governance' from most of its public communications and instead began to position the project in even broader terms as a 'one-stop shop for all C2G interactions'. This is in fact the current mission statement of the B1 project.

"Unfortunately, many people tend to see it in black and white terms. Is this e-governance or is this NOT e-governance? But the reality is grey. So we consciously present a lack of clarity about such aspects. That way, we can avoid many conflicts and move on.” (B1 team informant) 
and

"What is e-governance? What is meant by a one-stop shop for all C2G interactions? These abstract terms provide a way to manoeuvre around all kinds of difficult-to-meet demands. When people ask 'why are you not processing income tax returns?' they can say, 'sorry that was not part of our original mission'. Obviously, these are legitimate requests. I think they are working hard to introduce such services. But they can't really introduce them straightaway. We are in a complex and unpredictable environment." (citizen informant)

The B1 team has also been criticized for being evasive about why it has adopted a Microsoft technology platform for B1 instead of utilizing an ostensibly more ethical and reliable open-source platform:

"This is a debate we really try to avoid. I feel most citizens are not really concerned about proprietary software or open-source. Moreover, many of the officials in government departments are trained on Microsoft platforms. So although in the ideal world we shouldn't pay any kind of license fee etc., the real world at the moment is different. But technology experts don't agree and are quick to question us. We maintain a studied silence that can certainly be interpreted as lack of clarity. But really, this issue is a great potential distraction in the context we work in.” (B1 team informant)

Despite having an online presence, the B1 project in effect revolves around the walk-in CSCs. As the project progressed it became evident to the B1 team that the interests of the citizens would be better met if integrated services were offered mainly through CSCs. In other words, access to B1 services online is almost irrelevant to most people since less than $20 \%$ of Bangalore's citizens are active users of the internet. However, for the highly visible and vocal technology-centric audiences the success of the project is largely determined by whether or not government services can be accessed via the internet from 
the comfort of one's home. This is an audience, which the B1 team feels it cannot alienate because of the bad publicity they can bring to the project by being vocal about its failures: "We are deliberately not saying anything specific about accessing online services. The way things are going, we need more CSCs first, not web-based services. In fact, many people in Bangalore will not even know that B1 has a website! But the whole project runs the risk of being called backward, if we don't keep talking about direct internet access to public services. It is strange, but there we are.” (B1 team informant)

\section{Discussion}

The above analysis demonstrates how strategic ambiguity was employed by the B1 team during the implementation of the B1 project. Drawing on this analysis, we can clearly identify several important achievements of the deliberately ambiguous positions adopted by the B1 team. Firstly, the B1 team emphasized their commitment to the project in very broad and general terms without mentioning any specific goals. Clearly, 'goal ambiguity' (Cohen and March, 1986) was a central aspect of the implementation process. This approach, however, helped the B1 team to establish a working relationship with PCON, without having to explicitly commit to specific initiatives. As Miller (1989) observes, strategies in the public sector often involves communicating initial bargaining positions and general messages of intent. Articulating clear and concrete goals to stakeholders can seriously limit the scope and range of future negotiations (Bok, 1983; Davenport and Leitch, 2005). For the B1 team ambiguity was more than just stating an abstract initial position. As is the case with many governmental agencies in emerging economies, the B1 team did not possess the ICT skills to design and implement a complex project. Thus, ambiguity also served as a protective shield from behind which they could learn and develop a deeper understanding of the technological and organizational means through which complex services could be offered through the B1 
project in the future (see Matland, 1995). On the whole, strategic ambiguity created a situation reminiscent of Eisenberg's (1984) notion of 'unified diversity'. The project was able to present an appearance of unity, while accommodating diverse interpretations. For PCON the project was largely about providing basic services, while the B1 team had more expansive plans for the project. Although the B1 team's own ambitious plans for the project have yet remained unfulfilled, the use of ambiguity has allowed them to manage public expectations much better. For example, they have been able to claim success on the basis of how more than a million customers visit and transact at the CSCs every month (see EGovReach, 2012).

The second positive outcome of the strategic ambiguity of the B1 team relates to a core feature of a number of public ICT models in emerging economies. Most emerging economy governments are not ideologically averse anymore to the logic of joining hands with private partners to provide public services (see Kuriyan and Ray, 2009; Nayar, 2012). Such collaborations require maintaining a delicate balance between controlling private partners and at the same time allowing them to contribute creatively to the partnership (Reed, 1985; Davenport and Leitch, 2005). The B1 team's strategy in this regard had clear shades of both 'means ambiguity’ and 'authority ambiguity’ (Cohen and March, 1986) and they also brought some important benefits to the project. As described earlier, the B1 team's lack of clarity in articulating how much support they would provide and how much authority was actually delegated to PCON for marketing the initiative spurred the creation of highly decentralized, and ultimately very effective, marketing techniques. In other words, it is evident that the unclear rules surrounding a) the means by which the project was going to be marketed and b) the delegation of 'marketing' authority to PCON, allowed 'sensemaking to happen with maximum discretion' in the relational space between the B1 team and PCON (Davenport and Leitch, 2005: 1609). As a PCON informant put it: “They weren't being too clear. So we took the liberty of assuming that it was up to us to market B1.” This is not to suggest, of course, 
that strategic ambiguity will always motivate the private partner to improvise and innovate in favour of the project. But when strategic ambiguity is combined with bureaucratic commitment, a capable private partner and a workable business model, policies that address local needs may be implemented effectively. In this case, the ambiguity displayed by the B1 team shifted the responsibility of marketing to PCON, which clearly triggered an increase in the number of citizens using the services of B1. In this sense, strategic ambiguity facilitated positive changes at the local levels during the implementation of the project (Eisenberg, 1984).

An interesting aspect of the empirical data challenges the received wisdom about how private enterprises demand clarity in all their business relationships. If clarity was indeed the default expectation, why then did PCON accept the B1 team's ambiguity towards marketing and not push for greater clarity in the organization of marketing responsibilities? Some of the early cross-cultural management research might provide a clue. Pascale and Athos (1981, p.102) have noted that the demand for clarity and explicitness is only 'a cultural assumption' but not 'a linguistic imperative.' The important but unstated implication of this argument: since 'clarity' is only a cultural assumption about normal state of affairs, its opposite - 'lack of clarity' - could also represent normal state of affairs in some cultural contexts. Indeed, managers at PCON believed that ambiguous 'twists and turns' were embedded in any business relationship with governments in India and had to be coped with stoically as long as there weren't too many extreme shifts in policy. In other words, although surprised initially, informants at PCON were not really perturbed by the B1 team's lack of clarity about marketing. As a senior manager at PCON explained: “We have to be ready to deal with this lack of clarity. It is a cultural thing with governments here. If we start demanding clarity all the time, we wouldn't be able to get into any business with the government." Thus, it appeared that PCON accepted the B1 team's projection of strategic ambiguity as the reality 
they had to work with and not as something they had to oppose on universal principles of clarity. Some positive outcomes of strategic ambiguity, therefore, can also be linked to the cultural expectations held by various actor groups about the institutional context and structures.

Thirdly, strategic ambiguity in public communications gave the B1 team the flexibility to adapt the project to contextual contingencies. For example, the 'e-governance' motto in the early stages of the project and the 'one-stop shop for C2G interactions' label in the latter stages of the project were broad enough to accommodate a wide variety of services and it did not pin the B1 team down to any specific interpretation of what the B1 project was actually about. When citizen groups questioned the absence of a particular service in the B1 portfolio, the broad objectives and labels made it possible for the B1 team to deny that the service in question was ever intended to be provided via B1. Put differently, strategic ambiguity offered the B1 team what communication scholars refer to as 'plausible deniability' (Eisenberg, 1984; Pinker et al., 2008). Being able to deny a particular interpretation as invalid and to successfully defend such a denial legally is of special importance in emerging economies like India, where public interest litigations are increasingly common and can lead to public projects being stalled indefinitely, while courts deliberate for years on end. Here again, the B1 team's strategic ambiguity must not be confused with situations where implementation teams are unreliable and sloppy, and hence simply try to wriggle out of difficult situations through misleading statements. The B1 team continued to engage with many government departments and consistently strived to introduce new services through B1. But the use of strategic ambiguity was crucial since it ensured the continuity of the project and also gave the B1 team flexibility with regards to its future options (see Naisbitt, 1982; Eisenberg, 1984; Matland, 1995). 
Overall, the experience of the B1 team shows that strategic ambiguity can have many positive effects, and in contrast too much clarity can limit options and lead to costly commitments and conflicts (see Ring and Perry, 1985; Jarzabkowski et al., 2010). In ambiguous public policy contexts many questions may find answers only through experimentation (Matland, 1995). The B1 team's strategy underscores how sufficiently ambiguous approaches can help take projects forward and how the vision, mission, plans and technological abilities can be refined, reformulated and strengthened during implementation (Davenport and Leitch, 2005; Sillince et al., 2012). By minimizing debilitating conflict, strategic ambiguity may provide an opportunity for 'bureaucratic entrepreneurs' (Matland, 1995) such as the B1 team to shape policy and to address local needs directly.

\section{Theoretical contributions}

This study contributes to the literature on ambiguity in organizations by demonstrating how strategic ambiguity is a core aspect of public ICT innovations. It reiterates the significance of strategic ambiguity as a resource at various stages of the implementation process. Whereas much of the theory on implementation of public ICT innovations emphasizes careful strategic planning and shuns any reference to using ambiguity strategically, the B1 project provides us some useful theoretical insights into how strategic ambiguity works. As an instrument of action, strategic ambiguity generates a working consensus between groups, thus helping to maintain an acceptable rather than a conflict-creating definition of evolving situations (Eisenberg and Witten, 1987; Sillince et al., 2012). From the case, it is also evident that strategic ambiguity performs an important information control function (Leitch and Davenport, 2002). The adoption of ambiguous positions helps actors strategically manage the nature and extent of information disclosed to various audience groups. As Goffman (1963) observes, actors employ such information control strategies to handle contingencies 
effectively and to stabilize their relationships with significant others. In this sense, the information control function of strategic ambiguity also contributes to the effective management of key relationships. The B1 case also suggests that strategic ambiguity can delegate authority to stakeholder groups in ways that empower rather than constrain the implementation process (see Davenport and Leitch, 2005). Although contrary to the widelyheld belief that unambiguous prior assignment of concrete responsibilities to specific actors is central to implementation success, the empowerment argument finds support in studies, which show how leaving contractual obligations vague can actually give entities significant freedom and manoeuvrability (see Bernheim and Whinston, 1998). Further, deliberate incorporation of vagueness provides much needed interpretive flexibility to actors in their attempts to justify the current status and proposed future trajectories of a project. Thus, in a counter-intuitive way purposeful equivocation can have a significant positive impact on the continuity of public sector ICT innovations.

From the evolution of the B1 project, we also see that strategic ambiguity is invariably a precarious and unsettling condition. As parts of the empirical data show, ambiguous attitudes of an implementation team may be questioned and criticized periodically by demanding audiences. There are echoes here of Eisenberg's (1984) astute observation: although actors may incorporate high levels of strategic ambiguity in their interaction with audiences, audiences may perceive only a low level of ambiguity in what is being communicated. For instance, the B1 team's promise of ‘e-governance’ was interpreted by some audiences as a clear commitment to providing certain specific types of services. This audience clearly expressed their anger at how the project was unfolding, which then required the B1 team to use a different label to describe the project's mission. Therefore, strategic ambiguity demands frequent re-articulation and shifting of positions. It is therefore a recursive and emergent strategy, rather than a one-off approach. 


\section{Why does strategic ambiguity work?}

One question emerging out of this above discussion requires a much closer scrutiny. In fact, this query has rarely been addressed in empirical research: if strategic ambiguity is inevitably a precarious condition, why does it work so effectively as a resource in the implementation of public ICT innovations? This leads us to a fundamental premise that governs theory development about implementation of public ICT initiatives in general. It is felt that stakeholders always demand clarity and precision from implementation teams. While this is no doubt true in a general sense, as B1 shows, there could be many variations in specific institutional environments. The demand for clarity need not always be universal. In contexts that are inherently complex and unclear, stakeholders may be reasonably tolerant of ambiguous norms than they otherwise would. We may refer to such settings as inherently ambiguity-prone contexts, where stakeholders (e.g. private-sector partners) learn to cope with the prevailing lack of clarity, instead of blatantly resisting it. Thus, the adoption of strategic ambiguity can be effective, even though it appears precarious at times, because of the presence of a larger institutional culture that is willing to tolerate and operate within an ambiguous implementation framework. In this study, such cultural attributes were most marked in PCON's responses to the B1 team's ambiguous strategy. As a corollary to this argument, we may add that when cultural milieus undergo a gradual change and move towards that pole of the continuum where lack of clarity is not tolerated, strategic ambiguity may progressively lose its effectiveness.

\section{Contextual ambiguity}

In addition to exploring how and why strategic ambiguity works, it may be useful to reflect on the reasons why public ICT implementation contexts are ambiguous in the first place. In the particular case of emerging economies, while public ICT innovations aim to plug specific institutional voids, they are also simultaneously constrained in their operations by the effects 
of a much larger array of institutional voids. For instance, poor governance structures, weak legal enforcement of contracts, inadequate auditing trails, ineffectual public policy think tanks and the absence of solid inputs from independent research-led universities can add serious instability and uncertainty to the planned trajectory of a project (see Madon et al., 2007; Mair and Marti, 2009; Dhanaraj and Khanna, 2011). Clearly, these drawbacks inject significant ambiguities into the institutional context, leading to a state, which we may inductively theorize as 'high contextual ambiguity'.

When explaining processes of ambiguity, there is therefore a need to make the important analytical distinction between ambiguity embedded in the context (contextual ambiguity) and the ambiguous action of situated actors. It is clear from the B1 story that strategic ambiguity is constructed by actors who operate in an environment characterized by high contextual ambiguity, which itself is an on-going consequence of what actors are doing. With this insight, this paper adds to the small but growing stream of research that emphasizes the ‘duality’ of ambiguity (see Jarzabkowski et al., 2010; Sillince et al., 2012). In other words, the evolution of the B1 project makes it evident that ambiguity can be understood both as a medium that produces action as well as an outcome of action. Finally, the B1 case makes it obvious that strategic ambiguity alone is not implicated in the emergence of positive implementation outcomes. Although it is the main focus of the paper, strategic ambiguity is best understood in concert with a careful analysis of a) the viability of ICT innovation implementation models and b) the commitment and leadership of situated actors.

\section{Contributions to the literature on public ICT innovation in emerging economies}

This paper contributes to the literature on ICT innovation in emerging economies in three ways. First, it provides an empirical illustration of how relationships with the private sector are managed during the design and implementation stages of a public ICT innovation. Given that the technological capabilities of governments in emerging economies are often 
underdeveloped, private sector-public sector collaborations can create innovative projects which are scalable and sustainable. From the private sector's perspective, public ICT innovations are more commercial ventures and less altruistic endeavours. The contrasting long-term motives of the two sides ensure that the relationship is inevitably strained and tense. While private partners may negotiate hard to shift policy objectives to suit their ends (e.g., lobby for the introduction of relatively easier to manage C2B services rather than more complex C2G services), public sector implementation teams need to ensure that the project actually alleviates local problems and does not simply help the private partner accumulate profits. Thus, careful and effective management of the relationship with the private partner is a vital component of public ICT innovation in emerging economies.

The second contribution of the paper is to show how public ICT innovations in emerging economies evolve through the recursive interaction of a broadly stated initial goal with the realities of the micro-level institutional setting (see Matland, 1995). Guiding this recursive interactions are members of implementation teams who work with local actors and try to advance the innovation in useful ways. In this sense, outcomes of public ICT innovations, by and large, develop as 'bottom-up’ processes. Finally, this paper takes issue with the notion that public ICT innovations in emerging economies are mostly about providing government services online and enabling citizens to directly access such services via the internet. This is a very naive view of the potential of ICT for emerging economies. Despite technological advancements, as a proportion of the overall population, very few people in emerging economies are computer literate and have direct access to the internet. Therefore, it is only through the functioning of physically present mediating structures, such as the CSCs in the B1 project that we may be able to better understand the workings and outcomes of public ICT innovations (see James, 2004; Mistry, 2005; Kuriyan and Ray, 2009). This raises the 
important question: to what extent has the B1 project really been successful and more generally, how can we assess the success of public ICT innovations in emerging economies?

\section{Judging the success of public ICT innovations in emerging economies}

In assessing public ICT innovations in emerging economies, the central concern of scholars appear to be whether 'true' ICT-enabled governance has been achieved or not. Here, mechanisms of ICT governance seen in advanced economies like Singapore, UK, Australia, Canada and the US are often used as proxies and standards to judge 'true' sophistication and technological complexity of the services offered. The main focus is on clear and explicit strategic plans, precise implementation models and objective measures of success based on the initial goals. But as the B1 case shows, in the context of emerging economies, because of the very fact that they are still 'emerging', significant ambiguity can exist throughout the implementation process starting from the design and planning stages. The ICT infrastructure available at the disposal of implementation teams often outpaces the preparedness of the institutional infrastructure. Given that policy implementation teams have to contend with a serious of institutional voids, it is highly probable that ICT innovations may stumble along in unstructured ways, producing unpredictable outcomes. As noted earlier, such a process of decision making has been described as the garbage can model of implementation (Matland, 1995; Sillince et al., 2012). In such ambiguous contexts should success be measured only using assessment models that abhor ambiguity or can we adopt broader evaluation standards that attach a higher normative value to the overall positive effects of ICT innovations? The B1 project has allowed many citizens to access very basic services through the CSCs each month. Especially when set against the pre B1-era the project has simplified the life of many people. But clearly, when compared with how public ICT innovations have transformed governance in other countries the accomplishments of B1 can be termed as very modest. 
Further, the ethics of offering C2B services through what is claimed to be a 'government-led' public ICT project can also be questioned. There are echoes here of some of the well-known problematic consequences of getting the private sector involved in projects of public interest (see Stiglitz 2002, 2006).

Stiglitz (2002) has argued that the 'sequencing and pacing' of innovative reforms is crucial, especially in emerging economies. Rapid introduction of innovative reforms before supporting institutional mechanisms and structures are put in place can end up benefiting only a few. Thus, attempts to initiate ICT-enabled land reforms (for example) when necessary underlying legal safeguards and structures are still non-functional often end in abject failures. (see Prakash and De, 2007). Similarly, providing direct internet access to government services before citizens are equipped to take advantage of ICT directly can only be labelled a technological success but not a policy success. So, from the perspective of careful sequencing and pacing of public ICT innovations, I would suggest that B1 is a good illustration of a policy success despite the on-going lack of clarity about when and how more advanced services would be integrated into the project and despite B1's web-based services making up less than $1 \%$ of the overall transactions handled by the project. The project can still be called a success mainly because it is structured in a manner that is relevant to a large segment of the population and it offers services that demonstrably brings the benefits of ICT, albeit modest ones, to citizens. Recent reports show that CSCs achieve a monthly turnover of more than US \$1.6 million and handle more than 10 million transactions in a year (EGovReach, 2012) figures that are indeed noteworthy in this setting. So, perhaps John Kerry’s comment referred to in the introduction section of this paper was not really as far away from the truth as it appears. To wit, although Bangalore is not 'wired' in the direct sense of the term, projects like B1 (through its CSCs) are ensuring that a high proportion of the population are beneficiaries of what can be termed 'indirect wiring'. 
For policy designers in emerging economies, the evolution of the B1 project emphasizes the possibilities of implementing public ICT innovations as a series of bottom-up incremental experiments, particularly when ambiguity surrounds the level of available support from all relevant stakeholders. When the innovations address important voids- which are perceived as such not only in theoretical formulations of ICT-enabled governance, but by the target groups themselves - in the local environment, they are more likely to be scalable and sustainable. Indeed, projects along the lines of B1 are now being replicated in many other parts of the Karnataka state (Chandrashekhar, 2012). The B1 project also suggests ways in which public ICT implementation teams may utilize strategic ambiguity to manage relationships with multiple stakeholders. One major challenge for implementation teams is to devise bargaining and negotiating techniques so that commercial interests of the private partner alone do not shape the project trajectory. There is always a lurking danger of public ICT innovations turning into lucrative businesses for private enterprises with limited relevance for large sections of the population. Also, for public ICT innovations with ambiguous and evolving objectives, implementation teams and citizen groups need to focus more on 'formative evaluations that describe the process and describe the way outcomes are arrived at' (Matland, 1995: 166) rather than attempting to measure success using objective standards borrowed from completely different socio-economic contexts.

\section{Viewing strategic ambiguity in perspective}

Notwithstanding the empirical data presented, this paper does not make a case for celebrating or glorifying ambiguity in any way. It has to be acknowledged that the full range of public services and reforms that ICT innovations can drive are rarely exploited in an institutional environment dogged by uncertainty and vague objectives. As evident from parts of the case, lack of clarity and vagueness brings with it some serious disadvantages. Until now the B1 
project has managed to provide a set of important, but only basic public services. With a clearer purpose and strategic focus, the B1 project could have created a robust institutional infrastructure capable of providing more useful services (e.g., in areas such as driver licensing, property tax and land registration processes; see Table 1). Ambiguity, therefore has somewhat stifled the B1 project and limited its reach. Similarly, although the ambiguous approach to marketing has led to some positive outcomes it might not compare favourably to what can be achieved through a purposeful and detailed marketing plan.

As mentioned at various points in this paper, the ambiguity in the B1 team's approach towards the type of services to be offered through the project has also meant that a range of C2B services are now a part of what is ostensibly a public ICT innovation project. This is hardly an ideal situation since it has to some extent diluted and compromised the essence of the project. In emerging economies, many public projects launched in partnership with private entities appear to be mostly filling the coffers of the partner company, creating very little public value in the process (see Nayar, 2012). The somewhat unclear nature of the relationship with private players carries with it a serious risk of projects like B1 drifting away from providing useful public services, in particular, for the less privileged sections of the society (see Kuriyan and Ray, 2009). Thus, ambiguity about a public ICT innovation project could further escalate because of the introduction of services that contradict its broadly stated objectives. This type of ambiguity can also raise suspicion about vested interests in the private sector playing an unacceptably large role in defining and determining public interest.

These above concerns help provide a more systemic and balanced view of the accomplishments of ambiguity, suggesting that it is not something to be celebrated as an entirely desirable condition. However, these concerns do not take away from the main arguments of the paper, which show how strategic ambiguity plays an influential role in guiding the implementation process of a public ICT innovation towards reasonable success. 


\section{Limitations}

The discussion above relates to a single ethnographic case - the B1 project. Needless to say, there are bound to be variations in the extent to which these findings apply to other emerging economy contexts. In fact, I must point out that even within India, Karnataka is clearly one of the more progressive states with a dedicated department to oversee public ICT projects (for a good discussion on public ICT projects in other Indian states, see Kuriyan and Ray, 2009 and Bussell, 2012). Such macro-institutional factors might have certainly played a role in how B1 has evolved over the years. However, I have not considered them in this paper. The findings may also be less applicable to emerging economies where democratic and decentralized forms of governance are not well-developed. In such cases, implementation may always follow well-defined and non-ambiguous paths, consequent to decisions taken by powerful central bodies. By design, this paper privileges the perspective of the B1 team although I interviewed and observed PCON managers, CSC managers, CRs and many citizens who accessed B1's services. Further, I did not speak to any representatives from the various government departments and business enterprises whose services are now offered through the B1 project. Finally, although the institutional context of the emerging economies amplify the effects of ambiguity and bring them into sharper focus, it must be acknowledged that ambiguous contexts and the pointed use of strategic ambiguity are not restricted only to emerging economies. They are certainly used in many global settings.

\section{Concluding remarks}

In this paper, I examined how strategic ambiguity is deployed by key actors to shape and guide a specific public ICT innovation in Bangalore, India. The evolution of the B1 project provides empirical insights into how deliberate lack of clarity and the adoption of broad labels in interaction with audiences can be central to the implementation of public ICT 
innovations, especially in emerging economies. I have also suggested that broader evaluation standards are necessary to assess the impact of public ICT innovations on local environments. Future research can extend this study to other institutional contexts and assess the potential of strategic ambiguity to generate and implement innovative ideas. Such studies may also aim to examine how differences in contextual conditions (e.g., variations in the commitment levels of the bureaucracy and the private partners) may influence the effectiveness of strategic ambiguity. Given the overarching discourse of structure and order in strategic planning and implementation, more empirical work is also needed to explore the limits of strategic ambiguity in relation to public ICT innovation in emerging economies. This paper offers a modest starting point for such efforts.

\section{References}

Benson, B, Niou, E. Comprehending Strategic Ambiguity: US policy toward Taiwan security [WWW document] http://taiwansecurity.org/IS/IS-Niou-0400.htm (accessed $28^{\text {th }}$ October, 2012).

Bernheim, B.D. and Whinston, M.D. (1998). Incomplete Contracts and Strategic Ambiguity, American Economic Review 88(4): 902-932.

Blumer, H. (1969). Symbolic Interactionism: Perspective and Method, New Jersey: PrenticeHall.

Bok, S. (1983). Secrets: On the Ethics of Concealment and Revelation, New York: Pantheon Books.

Burke, K. (1962). A Grammar of Motives, Los Angeles: University of California Press.

Bussell, J. (2012). E-Governance and Corruption in the States: Can technology serve the aam aadmi, Economic and Political Weekly 47(25): 77-85.

Chandrashekhar, N. Newly added Palike Areas to get B-One on Wheels [WWW document] http://www.deccanherald.com/content/219826/added-palike-areas-get-b.html (accessed $16^{\text {th }}$ January, 2012).

Cohen, L and Ravishankar, M.N. (2012). Doing qualitative business and management research in international and intercultural contexts. In G. Symon, and C. Cassell (eds.) The practice of qualitative organizational research: Core methods and current challenges, London: Sage Publications, pp.168-184. 
Cohen M.D., March, J.G. and Olsen, J.P. (1972). A Garbage Can Model of Organizational Choice, Administrative Science Quarterly 17(1): 1-25.

Cohen, M. D. and March, J.G. (1986). Leadership and Ambiguity: The American College President, Boston: Harvard Business School Press.

Cordella, A. and Bonina, C.M. (2012). A Public Value Perspective of ICT-Enabled Public Sector Reforms: A theoretical reflection, Government Information Quarterly 29(4): 512-520.

Davenport, S. and Leitch S. (2005). Circuits of Power in Practice: Strategic ambiguity as delegation of authority, Organization Studies 26(11): 1603-1623.

Deloitte-CFO Insights. Turning Strategic Ambiguity into Strategic Clarity [WWW document] http://deloitte.wsj.com/cfo/files/2012/06/DFPORH2012050200001.pdf (accessed 28 ${ }^{\text {th }}$

October, 2012).

Dhanaraj, C. and Khanna, T. (2011). Transforming Mental Models on Emerging Markets, Academy of Management Learning \& Education 10(4): 684-701.

Edwan D.H. (2009). A Symbolic Interpretation of the Lines of Effort through the Theory of Strategic Ambiguity (Published Master's Dissertation), Fort Leavenworth, Kansas: United States Army Command and General Staff College.

EGovReach. Shared Services Model of Karnataka for eGovernance [WWW document] http://egovreach.in/uploads/presentation/karnataka/shared_services.pdf (accessed 28 ${ }^{\text {th }}$ October, 2012).

Eisenberg, E. (1984). Ambiguity as Strategy in Organizational Communication, Communication Monographs 51(3): 227-242.

Eisenberg, E. and Witten, M.G. (1987). Reconsidering Openness in Organizational Communication, Academy of Management Review 12(3): 418-426.

Eisenberg, E. and Goodall, H. (1997). Organizational Communication: Balancing Creativity and Constraint, New York: St. Martin's Press.

Goffman, E. (1961). Asylums: Essays on the social situation of inmates and other mental patients, New York: Doubleday.

Goffman, E. (1963). Stigma: Notes on the management of spoiled identity, New York: Simon and Schuster.

Goffman, E. (1974). Frame Analysis: An essay on the organization of experience, New York: Harper and Row.

Government of Karnataka. Prime Minister's Award for Excellence in Public Administration Nomination Form for the Year 2009-10 [WWW document] http://www.karnataka.gov.in/egovernance/Documents/PM-Awards-GOK-Bone.pdf (accessed $19^{\text {th }}$ January, 2012). 
Hammersley, M. and Atkinson, P. (2007). Ethnography: Principles in Practice (3rd edn), New York: Routledge.

Heeks, R. (2000). The Approach of Senior Public Officials to Information TechnologyRelated Reform: Lessons from India, Public Administration and Development 20(3): 197205.

Heeks, R. (2002). Information Systems and Developing Countries: Failure, success, and local improvisations, Information Society 18(2): 101-112.

Heeks, R. (2010). Emerging Markets Development: The IT-enabled transformation of international development, Communications of the ACM 53(4): 22-24.

Heeks, R. and Stanforth, C. (2007). Understanding E-Government Project Trajectories from an Actor-Network Perspective, European Journal of Information Systems 16(2): 165-177.

Hjern, B. and Hull, C. (1982). Implementation Research as Empirical Constitutionalism, European Journal of Political Research 10(2): 105-16.

James, J. (2004). Reconstruing the Digital divide from the Perspective of a Large, Poor, Developing Country, Journal of Information Technology 19(3): 172-177.

Jarzabkowski, P., Sillince, J.A. and Shaw, D. (2010). Strategic Ambiguity as a Rhetorical Resource for Enabling Multiple Interests, Human Relations 63(2): 219-248.

Kanungo, S. (2003). Information Village: Bridging the digital divide in rural India, in S. Krishna and S. Madon (eds.) The Digital Challenge: Information Technology in the Development Context, Aldershot: Ashgate, pp. 104-123.

Karra, N. and Phillips, N. (2008). Researching “Back Home”: International management research as autoethnography, Organizational Research Methods 11(3): 541-561.

Kerschberg, B. How Xerox uses Analytics, Big Data and Ethnography to help Government Solve "Big Problems" [WWW document]

http://www.forbes.com/sites/benkerschberg/2012/10/22/how-xerox-uses-analytics-big-dataand-ethnography-to-help-government-solve-big-problems/ (accessed 31 ${ }^{\text {st }}$ October, 2012).

Khanna, T., and Palepu, K. (1997). Why Focused Strategies may be Wrong for Emerging Markets, Harvard Business Review 75(4): 41-51.

Khanna, T. and Palepu, K. G. (2010). Winning in Emerging Markets: A Roadmap for Strategy and Execution, Boston: Harvard Business Press.

Kimaro, H.C. and Sahay, S. (2007). An Institutional Perspective on the Process of Decentralization of Health Information Systems: A case study from Tanzania, Information Technology for Development 13(4): 363-390.

Kuriyan, R and Ray, I (2009). Outsourcing the State? Public-Private Partnerships and information technologies in India, World Development 37(10): 1663-1673. 
Leitch, S. and Davenport, S. (2002). Strategic Ambiguity in Communicating Public-Sector Change, Journal of Communication Management 7(2): 129-139.

Lowi, T.J. (1979). The End of Liberalism, New York: Norton.

Madon, S., Sahay, S. and Sahay, J. (2004). Implementing Property Tax Reforms in Bangalore: An actor-network perspective, Information \& Organization 14(4): 269-295.

Madon, S. (2005). Governance Lessons from the Experience of Telecentres in Kerala, European Journal of Information Systems 14(4): 401-416.

Madon, S., Sahay, S. and Sudan, R. (2007). E-Government Policy and Health Information Systems Implementation in Andhra Pradesh, India: Need for articulation of linkages between the macro and the micro, Information Society 23(5): 327-344.

Mair, J. and Marti, I. (2009). Entrepreneurship in and around Institutional Voids: A case study from Bangladesh, Journal of Business Venturing 24(5): 419-435.

Malinowski, B. (1922). Argonauts of the Western Pacific: An account of native enterprise and adventure in the Archipelagoes of Melanesian New Guinea, London: Routledge and Kegan Paul.

March, J.G. and Olsen, J.P. (1976). Ambiguity and Choice in Organizations, Oslo: Universitetsforlaget.

Matland, R.E. (1995). Synthesizing the Implementation Literature: The ambiguity-conflict model of policy implementation, Journal of Public Administration Research \& Theory 5(2): 145-174.

Miller, G. (1989). Unique Public-Sector Strategies, Public Productivity \& Management Review 13(2): 133-144.

Mistry, J.J. (2005). A Conceptual Framework for the Role of Government in Bridging the Digital Divide, Journal of Global Information Technology Management 8(3): 28-47.

Mukherjee, A, Nayar, L. Aadhar, A few basic issues [WWW document] http://dataprivacylab.org/TIP/2011sept/India4.pdf (accessed $13^{\text {th }}$ April 2012).

Myers, M.D. (1999). Investigating Information Systems with Ethnographic Research, Communications of the AIS 2 (23): 1-20.

Naisbitt, J. (1982). Megatrends, New York: Warner Books.

Noordegraaf, M. and Abma, T. (2003). Management by Measurement? Public management practices amidst ambiguity, Public Administration 81(4): 853-871.

Nayar, L. Public Private Perplexity [WWW document] http://www.outlookindia.com/article.aspx?282113 (accessed $1^{\text {st }}$ November, 2012). 
OECD (2011). Innovation in Public Service Delivery - Context, Approaches and Challenges, Paris: OECD Publishing.

Pascale, R.T. and Athos, A.G. (1981). The Art of Japanese Management, New York: Simon and Schuster.

Paul, J. and Strbiak, C.A. (1997). The Ethics of Strategic Ambiguity, Journal of Business Communication 34(2): 149-159.

Pinker, S., Nowak, M.A. and Lee, J.J. (2008). The Logic of Indirect Speech, Proceedings of the National Academy of Sciences 105(3): 833-838.

Prakash, A. and De, R. (2007). Importance of Development Context in ICT4D Projects, Information Technology \& People 20(3): 262-281.

Puri, S.K. and Sahay, S. (2007). Role of ICTs in Participatory Development: An Indian experience, Information Technology for Development 13(2): 133-160.

Rai, S., Pederson, M.K. and Kazakevičiūtè, A. (2010). A Framework for the Co-Creation of IT Innovation: Empirical results from India, Journal of Information Technology Case and Application Research 12(4): 13-36.

Rangaswamy, N. and Nair, S. (2010). The Mobile Phone Store Ecology in a Mumbai Slum Community: Hybrid networks for enterprise, Information Technologies \& International Development 6(3): 51-65.

Ravishankar, M.N., Pan S.L. and Myers, M. (2012). Information Technology Offshoring in India: A postcolonial perspective, European Journal of Information Systems advance online publication 17 July, doi:10.1057/ejis.2012.32.

Reed, M. (1985). Redirections in Organizational Analysis, London: Tavistock.

Regan, P.M. (1984). Personal Information Policies in the United States and Britain: The dilemma of implementation considerations, Journal of Public Policy 4(1):19-38.

Ring, P.S. and Perry, J.L. (1985). Strategic Management in Public and Private Organizations: Implications of distinctive contexts and constraints, Academy of Management Review 10(2): 276-286.

Sahay, S., Aanestad, M. and Monteiro, E. (2009). Configurable Politics and Asymmetric Integration: Health e-Infrastructures in India, Journal of the Association for Information Systems 10(5): 399-414.

Sahay, S, Sæbø, J.I., Mekonnen, S.M. and Gizaw, A.A. (2010). Interplay of Institutional Logics and Implications for Deinstitutionalization: Case study of HMIS implementation in Tajikistan, Information Technologies \& International Development 6(3): 19-32. 
Sarkar, S. Engaging Technology in Providing Public Services [WWW document] http://www.livemint.com/Industry/7GN0tcUJVN9ETPtst7qF4M/Engaging-technology-inproviding-civic-services.html (accessed 26 ${ }^{\text {th }}$ March, 2012).

Saxena, K.B.C. (2005). Towards Excellence in E-Governance, International Journal of Public Sector Management 18(6): 498 - 513

Sillince, J., Jarzabkowski, P. and Shaw, D. (2012). Shaping Strategic Action through the Rhetorical Construction and Exploitation of Ambiguity, Organization Science 23(3) 633-650.

Smith, M.L. (2011). Limitations to Building Institutional Trustworthiness through EGovernment: A comparative study of two e-services in Chile, Journal of Information Technology 26(1): 78-93.

Stafford, T.F. and Turan, A.H. (2011). Online Tax Payment Systems as an Emergent Aspect of Governmental Transformation, European Journal of Information Systems 20(3): 343-357.

Stiglitz, J.E. (2002). Globalization and its Discontents, New York: WW Norton.

Stiglitz, J.E. (2006). Making Globalization Work, New York: WW Norton.

Strauss, A. and Corbin, J. (1998). Basics of Qualitative Research: Techniques and Procedures for Developing Grounded Theory, CA: Thousand Oaks.

Vaara, E. (2002). On the Discursive Construction of Success/Failure in Narratives of Post Merger Integration, Organization Studies 23(2): 211-248.

Valdes, G., Solar M., Astudillo, H., Iribarren, M., Concha, G. and Visconti, M. (2011). Conception, Development and Implementation of an E-Government Maturity Model in Public Agencies, Government Information Quarterly 28(2): 176-187.

Van Maanen, J. (1979). The Fact of Fiction in Organizational Ethnography, Administrative Science Quarterly 24(4): 539-550.

Van Maanen, J. (2011). Ethnography as Work: Some rules of engagement, Journal of Management Studies, 48(1): 218-234.

Walsham, G. (1992). Decentralisation of Information Systems in DC's: Power to the people?, in S.C. Bhatnagar and M. Odedra (eds.) Social Implications of Computers in Developing Countries, New Delhi: Tata McGraw-Hill, pp. 197-208.

Walsham, G. (1995). The Emergence of Interpretivism in IS Research, Information Systems Research, 6(4): 376-394.

Walsham, G. and Sahay, S. (1999). GIS for District-Level Administration in India: Problems and opportunities, MIS Quarterly 23(1): 39-65.

Weerakkody, V, El-Haddadeh R., Sabol, T., Ghoneim, A. and Dzupka, P. (2012). EGovernment Implementation Strategies in Developed and Transition Economies: A comparative study, International Journal of Information Management 32(1): 66-74. 
Yackee, S.W. (2012). The Politics of Ex Parte Lobbying: Pre-proposal agenda building and blocking during agency rulemaking, Journal of Public Administration Research and Theory 22(2), 373-393.

Figure 1. Functional architecture of B1

Source: http://www.share4dev.info/kb/documents/4723.pdf

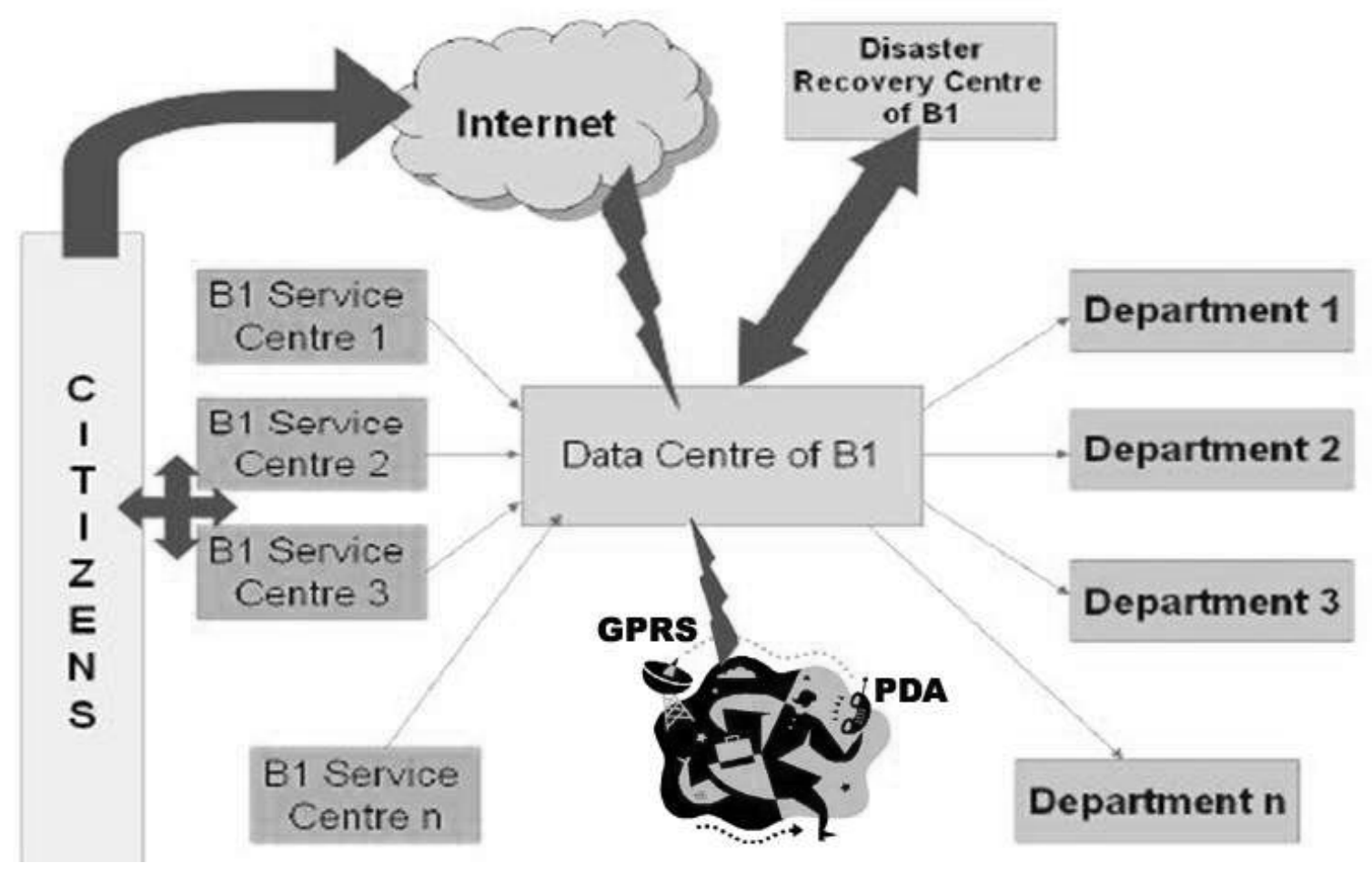

Figure 2. Ethnographic fieldwork for the B1 project

F1:1 $1^{\text {st }}$ round of fieldwork

F6: $6^{\text {th }}$ round of fieldwork

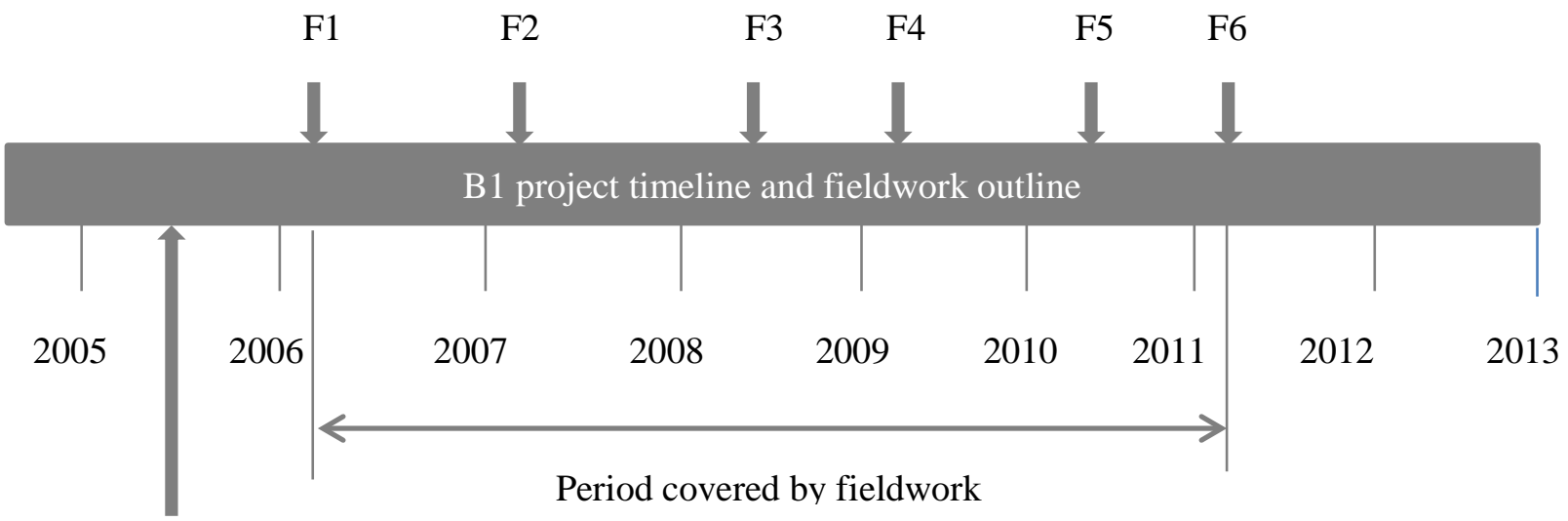

Launch of B1 
Table 1. Services at the CSCs

\begin{tabular}{|c|c|c|}
\hline Service offered & Department/organization & $\begin{array}{c}\text { Service } \\
\text { type }\end{array}$ \\
\hline Payment of property tax & $\begin{array}{l}\text { Bangalore Mahanagara Palike (BMP) - } \\
\text { the local municipal corporation }\end{array}$ & $\mathrm{C} 2 \mathrm{G}$ \\
\hline $\begin{array}{l}\text { Preliminary processing of } \\
\text { passport applications }\end{array}$ & Regional Passport Office (RPO) & C2G \\
\hline Issue of monthly bus passes & $\begin{array}{c}\text { Bangalore Metropolitan Transport } \\
\text { Corporation (BMTC) }\end{array}$ & $\mathrm{C} 2 \mathrm{G}$ \\
\hline Estimation of property value & Departments of Stamps and Registration & $\mathrm{C} 2 \mathrm{G}$ \\
\hline Fine payment service & Bangalore Police Service (BPS) & $\mathrm{C} 2 \mathrm{G}$ \\
\hline Payment of monthly bills & $\begin{array}{c}\text { Bangalore Electricity Supply } \\
\text { Commission (BESCOM) }\end{array}$ & $\mathrm{C} 2 \mathrm{G}$ \\
\hline Payment of monthly bills & $\begin{array}{c}\text { Bangalore Water Supply and Sewerage } \\
\text { Board (BWSSB) }\end{array}$ & $\mathrm{C} 2 \mathrm{G}$ \\
\hline $\begin{array}{l}\text { Payment of monthly bills } \\
\text { (telephone) }\end{array}$ & Bharat Sanchar Nigam Limited (BSNL) & $\mathrm{C} 2 \mathrm{G}$ \\
\hline Booking of Rail Tickets & $\begin{array}{c}\text { Indian Railway Catering and Tourism } \\
\text { Corporation Limited (IRCTC) } \\
\end{array}$ & $\mathrm{C} 2 \mathrm{G}$ \\
\hline $\begin{array}{l}\text { Booking of bus tickets for } \\
\text { country-wide travel }\end{array}$ & $\begin{array}{l}\text { Karnataka State Road Transport } \\
\text { Corporation Services (KSRTC) }\end{array}$ & $\mathrm{C} 2 \mathrm{G}$ \\
\hline $\begin{array}{l}\text { Applying for re-evaluation of } \\
\text { examination results (A } \\
\text { levels) }\end{array}$ & $\begin{array}{c}\text { Karnataka Secondary Education } \\
\text { Examination Board }\end{array}$ & $\mathrm{C} 2 \mathrm{G}$ \\
\hline $\begin{array}{l}\text { Applying for re-evaluation of } \\
\text { examination results } \\
\text { (undergraduate and } \\
\text { postgraduate) }\end{array}$ & Bangalore University & $\mathrm{C} 2 \mathrm{G}$ \\
\hline $\begin{array}{l}\text { Payment of monthly bills } \\
\text { (telephone) }\end{array}$ & $\begin{array}{c}\text { Private mobile telephone service } \\
\text { providers: Vodafone, Airtel, Reliance, } \\
\text { Cellone, Idea, Tata Indicom }\end{array}$ & C2B \\
\hline Money transfer services & Western Union Money Transfer & $\mathrm{C} 2 \mathrm{~B}$ \\
\hline $\begin{array}{l}\text { Payment of insurance } \\
\text { premiums }\end{array}$ & ING Life Insurance & C2B \\
\hline $\begin{array}{l}\text { Registration for vocational } \\
\text { training courses }\end{array}$ & Laqsh Academy & $\mathrm{C} 2 \mathrm{~B}$ \\
\hline
\end{tabular}


Table 2. Services on the B1 website

\begin{tabular}{|c|c|c|}
\hline Service offered & Department/organization & $\begin{array}{c}\text { Service } \\
\text { type }\end{array}$ \\
\hline Fine payment service & Bangalore Police Service (BPS) & C2G \\
\hline Payment of monthly bills & $\begin{array}{c}\text { Bangalore Electricity Supply } \\
\text { Commission (BESCOM) }\end{array}$ & C2G \\
\hline Payment of monthly bills & $\begin{array}{c}\text { Bangalore Water Supply and Sewerage } \\
\text { Board (BWSSB) }\end{array}$ & C2G \\
\hline $\begin{array}{c}\text { Payment of monthly bills } \\
\text { (telephone) }\end{array}$ & Bharat Sanchar Nigam Limited (BSNL) & C2G \\
\hline $\begin{array}{c}\text { Applying for re-evaluation of } \\
\text { examination results } \\
\text { (undergraduate and } \\
\text { postgraduate) }\end{array}$ & Bangalore University & C2G \\
\hline $\begin{array}{c}\text { Payment of monthly bills } \\
\text { telephone) }\end{array}$ & $\begin{array}{c}\text { Private mobile telephone service } \\
\text { providers: Vodafone, Airtel, Reliance, } \\
\text { Cellone, Idea, Tata Indicom }\end{array}$ & C2B \\
\hline $\begin{array}{c}\text { Payment of insurance } \\
\text { premiums }\end{array}$ & ING Life Insurance & C2B \\
\hline
\end{tabular}

\section{Appendix A. A screenshot of the B1 website}

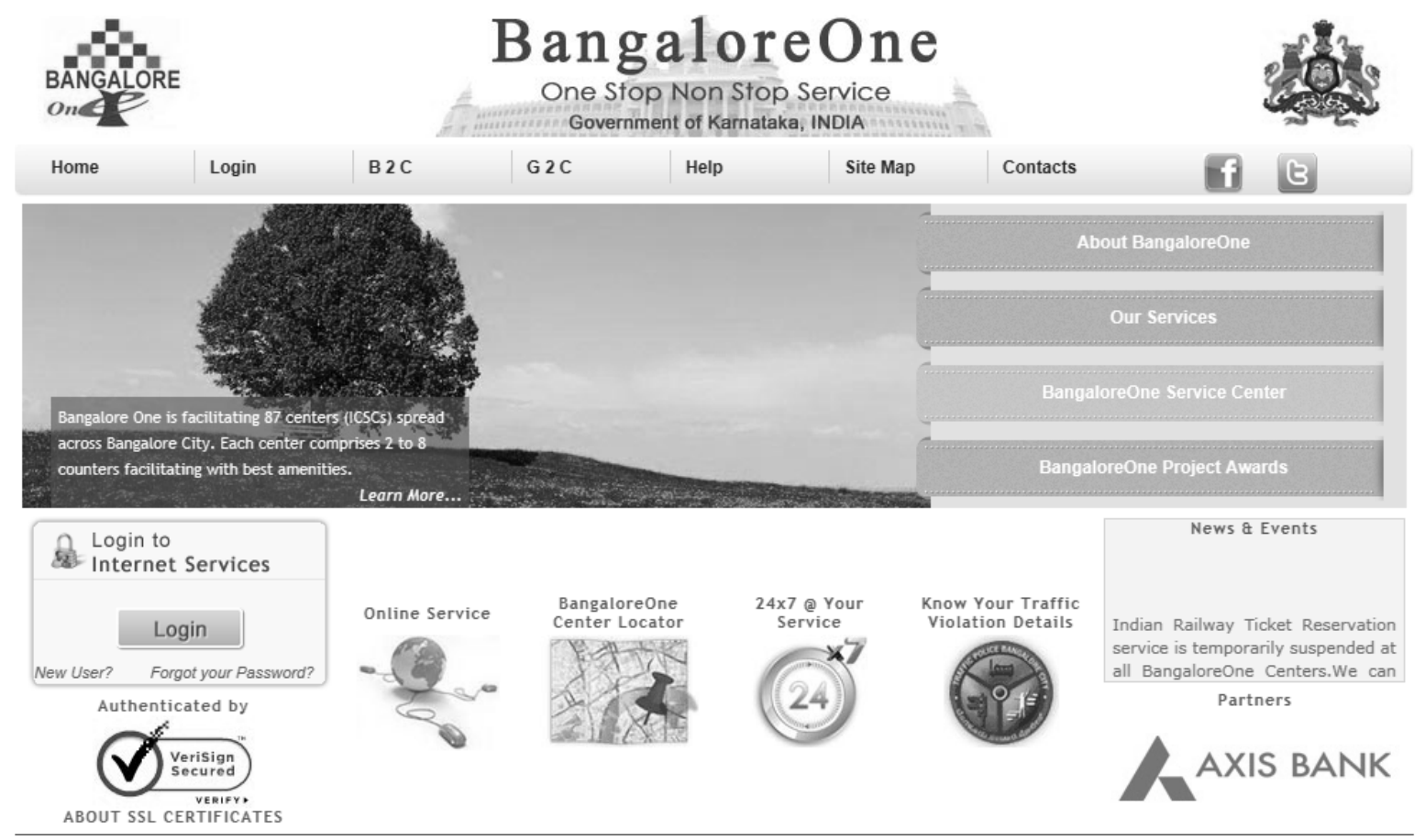




\section{Appendix B. CRs and customers at a B1 CSC}

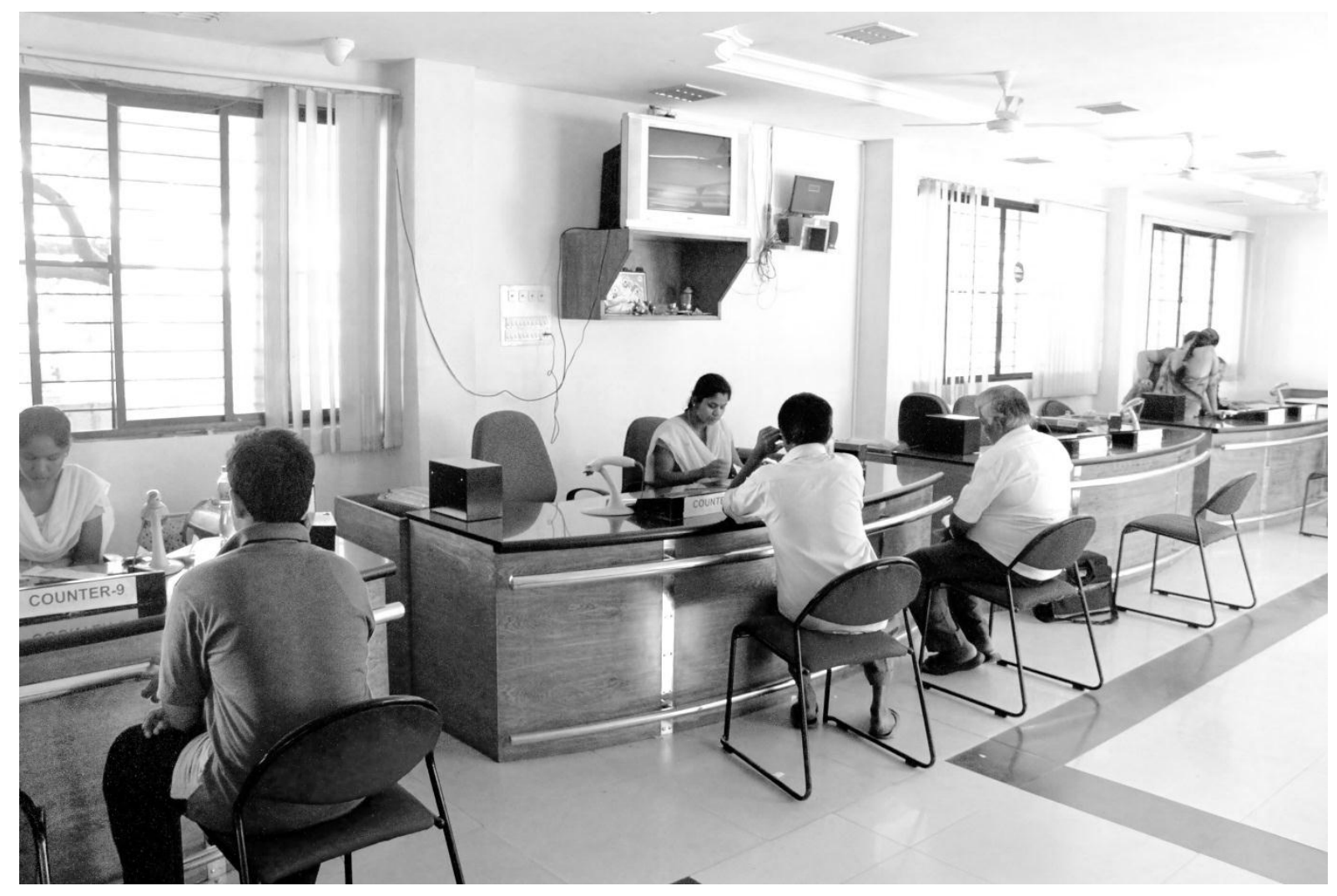

${ }^{i}$ Karnataka is a state in Southern India with a population of roughly 61 million. Bangalore city is the state's administrative capital. According to the 2011 Census of India, close to 9.6 million people live in Bangalore.

ii To preserve anonymity, I do not invoke specific roles and designations of informants. I use general terms such as 'B1 team informant' and 'PCON informant' when attributing quotes to informants.

iii Kannada is the main language spoken in Bangalore. It is the official language of the state of Karnataka.

\section{About the author}

M.N. Ravishankar is a Reader in Globalisation and Emerging Markets in the School of Business and Economics, Loughborough University, UK. His research interests span culture and its interface with strategy, offshore outsourcing of work and IT-enabled transformations in emerging markets. His research articles have appeared in journals such as Information Systems Research, European Journal of Information Systems, Information Systems Journal and Omega. 